\author{
Hana Kreisingerová \\ Ústav pro jazyk český Akademie věd ČR \\ oddělení vývoje jazyka
}

\title{
Vysvětlivky ve staročeském biblickém překladu prorockých knih*
}

Klíč ová slova: stará čeština, bible, biblické vysvětlivky, nejstarší staročeský překlad

\section{1. Úvod}

Písmo svaté, inspirované nejen svými světskými autory, ale i Božím působením, se svou podstatou vždy vymykalo ostatním typům textů, a z toho důvodu byl také vždy kladen značný důraz na chápání a interpretaci Písma v duchu křest’anského vidění světa. Zároveň však uznávaná Boží přítomnost při vzniku Bible nedovolovala text jakkoliv měnit, třebaže se jedná o text bohatý na obrazné a ne vždy zcela interpretačně jednoznačné pasáže. Obavy $\mathrm{z}$ možných nevhodných interpretací byly $\mathrm{v}$ raných fázích středověku samovolně eliminovány všeobecně nízkou vzdělaností evropské populace. Znalost čtení a psaní však během stř̌edověku postupně vzrůstala a zvláště poté, co se Písmo svaté začalo překládat i do národních jazyků, se okruh potenciálních čtenářů tohoto textu začal postupně rozšiřovat. Jednou z možností, jak případným nežádoucím výkladům předejít, bylo doprovodit biblický text doplňujícími komentáři a vysvětlivkami. Podobných výkladových skladeb exis-

* Př́íspěvek vznikl s podporou projektu MŠMT ČR: Výzkumné centrum vývoje staré a střední češtiny (od praslovanských kořenů po současný stav) č. LC 546. 
tovalo v Evropě velké množství, mezi nejoblíbenější patřila zvláště Glossa ordinalia n. výklad Petra z Troyes zvaného Comestor.

Textové vysvětlivky se staly součástí i nejstaršího úplného překladu Bible do češtiny a $z$ dnešního pohledu je můžeme považovat za specifický zdroj poznání dobového vnímání biblického textu, zároveň dokumentují nejrůznější překladatelské obtíže vyplývající z rozdílů mezi češtinou a latinou, z níž byl nejstarší úplný překlad pořízen, a jak se pokusíme v tomto př́spěvku doložit, bylo jich uživáno nepochybně i s úmyslem ovlivnit čtenářskou interpretaci textu.

Příspěvek bude rozdělen na několik částí. První z nich bude věnována stručnému popisu nejstaršího úplného překladu Bible do českého jazyka, jelikož okolnosti jeho vzniku jsou pro výklad vysvětlivek velmi podstatné. Okruh zkoumání jsme omezili na vysvětlivky v knihách prorockých. Chceme tak navázat na vystoupení Mgr. M. Pytlíkové, která se podobnému tématu věnovala na vzorku knih makabejských (viz Pytlíková 2010: 286-291).

\section{První úplný překlad Bible do českého jazyka}

První úplný překlad bible do českého jazyka pochází z druhé poloviny 14. stol. Vznikal tak v době všeobecné emancipace a rozkvětu českého jazyka a české kultury vůbec. Je spojován s obrodnými snahami Karla IV., který dlouhodobě podporoval kulturní vzmach českého státu a domácí jazyk Čechů označoval dokonce jako „linguu nobilis” (viz Kyas 1971: 59). Podle tvrzení některých badatelů (sr. např. Bartoš 1941: 6) to byl právě Karel IV., kdo také inicioval vznik českého překladu Pasionálu, jedné z nejvýznamnějších českých památek tohoto období. Tato skutečnost je významná zejména z toho důvodu, že autor staročeského Pasionálu nejenže patřil mezi velké osobnosti počátků českého písemnictví (a je mu mimo jiné přičítáno i autorství dalšího ze základních děl české prózy, Života Krista Pána), ale jak soudí napřs. i Vladimír Kyas (1971: 56), jeden z předních badatelů věnujících se biblickému překladu, podílel se tento autor nemalou měrou právě i na překladu nejstaršího úplného staročeského překladu bible.

Práce na překladu, započatá pravděpodobně už v 60 . letech 14. stol., nebyla dílem jednotlivce, ale celé skupiny autorů, jak o tom svědčí mj. některé překladové nuance mezi jednotlivými knihami, které zároveň daly vzniknout teorii o dvou samostatných překladatelských skupinách, podílejících se na 
překladu paralelně. Tyto překladatelské skupiny se lišily zejména výběrem překladových ekvivalentů za některé latinské výrazy (nejčastěji uváděným př́kladem je odlišný překlad latinského výrazu sacerdos, který první skupina překládala jako pop, druhá jako kněz). Podle Vladimíra Kyase měl právě $\mathrm{k}$ této druhé překladatelské skupině patřit i výše zmíněný překladatel Života Krista Pána a Pasionálu. Této skupině pak Kyas přisuzuje i konkrétní řádovou prŕíslušnost - předpokládá, že se jednalo o členy dominikánského řádu, kteří v této době měli v Praze vysoké učení a zároveň patřili coby kazatelé k denním uživatelům českého jazyka (viz Kyas 1971: 56).

\section{Charakteristika vysvětlivek}

Skutečnost, že je možné porovnávat překladatelský styl obou skupin, zároveň svědčí o jasné a ucelené koncepci, která celý podnik nutně provázela. Za jeden z př́iznaků této koncepce bychom pravděpodobně mohli označit i užívání doplňujících komentářů a vysvětlivek k textu, které se objevují (byt' v různé míre) ve všech biblických knihách. Těmito vysvětlivkami se rozumějí nebiblické vsuvky vkládané prŕímo do biblického textu. Hlavní důvod jejich zařazení je zcela zřejmý. Překlad bible vznikal v době, kdy se český jazyk teprve začínal užívat i pro vyšší stylové roviny, a jeho slovní zásoba proto pochopitelně nemohla překladatelům nabídnout dostatek překladových ekvivalentů pro všechny potřebné termíny. Biblický text zároveň pojednával v řadě př́padů o reáliích českému prostředí velmi vzdálených. Proto bylo v podstatě nutností ulehčit čtenáři recepci textu prostřednictvím doplněného výkladu. Tato potřeba se zdála o to potřebnější, že první překlad byl nejspíše přeložen pro některý z ženských klášterů v Praze.

Vysvětlivky měly podobu jedno či víceslovných doplnění a byly do textu vkládány bud' př́mo bez jakéhokoliv ohraničení, nebo byl jejich výskyt signalizován pomocí výrazů totiž, to jest, točišto ap. Jak již bylo zmíněno výše, vysvětlivky se objevují ve všech biblických knihách, hojnější jsou však zvláště v Knihách královských, což by mohlo být dáno i povahou textu, v menší míře je však nalézáme např. v stylově obdobných knihách Paralipomenon - míra komentování textu tedy patrně závisela spíše na vůli konkrétního překladatele (v tomto pohledu je zajímavé, že výše zmiňovaný autor Pasionálu měl být podle Kyase autorem právě bohatě okomentovaných Knih krá- 
lovských ${ }^{1}$ ). Knihy prorocké patří co do počtu vložených vysvětlivek ke knihám spíše chudším (jedna kniha velkých proroků v průměru obsahuje zhruba 60 vysvětlivek, v malých prorocích jejich počet nedosahuje ani deseti výskytů na knihu, oproti tomu ve zmiňovaných Knihách královských je jich v každé knize v průměru 220).

\section{Třídění a rozbor vysvětlivek}

Aby bylo možné s vysvětlivkami dále pracovat, je nutné si je nejprve roztř́idit do menších skupin. Prvním možným východiskem jejich rozčlenění může být dělení podle typu výrazu, k němuž odkazují. Na tomto základě můžeme vyčlenit dvě základní skupiny, a to skupinu komentující propriální výrazy a skupinu vztahující se $\mathrm{k}$ apelativům.

Všeobecně přitom platí, že propriální výrazy jsou komentovány častěji než výrazy apelativní, odlišný stav najdeme pouze v knize Ezechiel, knize s vůbec nejvyšším počtem vysvětlivek v rámci prorockých knih (je jich zde přes 90). Tato skutečnost je dána především charakterem textu Ezechielova proroctví, zatíženého velkým počtem interpretačně náročných míst, vyžadujících obsáhlejší komentár̆, o čemž svědčí i výrazná převaha víceslovných vysvětlivek nad vysvětlivkami jednoslovnými.

\subsection{Vysvětlivky propriální}

Propriální složka je v biblickém textu velmi hojně zastoupena, a to jak v oblasti antroponym, tak v oblasti toponym, a není proto divu, že patří ke skupinám v prorockých knihách nejhojněji komentovaným. V převažující míře se však vysvětlivky objevují pouze u toponym, antroponyma jsou jejich pomocí komentována jen zcela výjimečně. (Jejich identifikace v textu coby označení př́slušníka lidského rodu je pochopitelně nejméně komplikovaná.) Po formální stránce je tato skupina poměrně jednotná. V převážné míře se jedná o jednoslovné (či pouze o ukazovací zájmeno ten, ta, to rozšířené) pojmenování př́islušným toponymem označovaného objektu či místa, umožňující čtenáři neznámý výraz jasněji identifikovat.

1 Viz Kyas 1971: 27. 
Př́́klady tohoto typu ${ }^{2}$ :

(1) Ale hlava syrská Damascus (město) a hlava Damaška Razin a ještě pět a šestdesát let a přestane Efraim slúti lid (Iz 7,8)

(2) ... a chvála lesu jeho a Carmela (hory) jeho ot dušě až do těla strávena bude. A bude strachy zběhem (Iz 10,18)

(3) Břiemě púštného moře. Jako vichrové s (toho větra jménem) Afrika... (Iz 21,1)

(4) Posilte sě, synové Benjamin, prostř̌ĕd Jeruzaléma a na (tej tvrzi) Thecua trubte v trúbu $(\mathrm{Jr}$ 6,1)

(5) A zbil jest král babylonský syny Sedechiášovy v (tom městě) Reblata $($ Jr 39,6)

Bližší průzkum propriálních vysvětlivek ukázal, že volba komentovaných toponym nebyla volena zcela systematicky. Některá z nich byla komentovaná v rámci jedné knihy opakovaně, některá naopak vůbec. Přesto by snad bylo možné vysledovat jistou tendenci komentovat vybraná toponyma především v místech jejich počátečních výskytů a postupně od doplňování upřesňujících vysvětlivek upouštět. Nekomentována zůstávala především všeobecně známá toponyma, jako Babylon, Jeruzalém, Sion, Egypt ap., ale najdeme mezi nimi i některá místní jména méně známá (Efraim, Galad, Cedar ap.).

Funkce tohoto typu vysvětlivek je poměrně jasná a míra jejich vlivu na vyznění textu poměrně nízká. $V$ rámci propriálních vysvětlivek však existuje ještě jedna menší podskupina, z pohledu interpretačního zajímavějšś. Ta se od předchozí liší jak délkou (většinou se jedná o víceslovná doplnění), tak i charakterem: Tyto vysvětlivky nesloužily v prvé řadě k identifikaci pojmenovávaného objektu či místa, ale přinášely výklad významu užitého pojmenování. Čtenár neznalý řečtiny a hebrejštiny tak byl tímto zpơsobem upozorňován na další roviny biblického textu, které by mu jinak zůstaly skryté. Zařazení tohoto typu výkladů zároveň svědčí o překladatelových znalostech problematiky hebrejských jmen, tématu v tomto období všeobecně oblíbenému, jak o tom svědčí mj. i výskyt celého obsáhlého souboru těchto výkladů v Litoměřicko-třeboňské bibli, památce reprezentující mladší revidovanou podobu prvotního překladu.

${ }^{2}$ Všechny následující příklady (pokud není uvedeno jinak) jsou čerpány z Bible olomoucké. 
Př́íklady tohoto typu:

(6) Běda Arieli, Ariel město (točíš Jeruzalém) ... (Iz 29,1)

(7) Zdali ještě v malém času a v krátkém obrátí sě Libanus (ta hora, točíš ta hora krásným dřievím okráslená) v Chermel (točíš v jalovú horu) a Chermel za les mněn bude (Iz 29,17)

(8) Nebo připraveno jest jakž včera Thophet (to jest údolé pekelné propasti), od krále připraveno, založeno a rozšířeno hlubocě (Iz 30,33)

(9) ... tu kdež byla postavena modla Zeli (točíš Baal, to jest vstiekanie) ku pomstě a $\mathrm{k}$ dráždění hněvánie $(E z) 8,3)$

\subsection{Vysvětlivky apelativní}

Rozsáhlou skupinu vysvětlivek apelativních je nutné ještě dále rozčlenit. Pro naše potřeby si vyčleníme dvě hlavní skupiny, skupinu tzv. překladově-interpretační a skupinu významově-interpretační.

\subsubsection{Vysvětlivky prekladově-interpretační}

Do první skupiny jsme zařadili vysvětlivky, kterými se překladatelé snažili překlenout obtíže související s nedostatečnou slovní zásobou češtiny a nejistotou ohledně zvoleného překladu.

Jednou z možností, jak se vypořádat při překladu s biblickým líčením v českém prostředí neznámých reálií, bylo ponechání neznámého výrazu v původním latinském znění a doplnění textu o vysvětlující komentár. Tento způsob byl v př́padě prvního překladu poměrně častý a byl užíván zejména $v$ prŕípadě pojmenování neznámých zvířat či rostlin, v našem úseku se pak častěji setkáváme i s výrazy z okruhu starověkého metrického systému. Tento typ má svým charakterem velmi blízko k vysvětlivkám propriálním, a to včetně formální podoby (i ony jsou převážně uvozeny pouze pomocí zájmena).

Př́klady tohoto typu:

(10) Bydliti bude vlk s beranem a pardus (to zvieře) s kozlem přebývati bude (Iz 11,6)

(11) A bude sě kochati dietě od prsu v dúpiech aspida (hada tak řečeného) $(\operatorname{Iz} 11,8)$

(12) ... a vodu u mieru píti budeš, šestú čiest (té měřicě) hin $(E z \quad 4,11)$ 
(13) ... vykládali sú železo kované, klí předrahý a calamus (to kořenie, z něhožto ten klí padá a kape) (Ez 27,19)

(14) Tu otpočívati budú almia (to zvieřě) a nalezlo jest sobě otpočinutie (Iz 34,14)

Překladatelovy obtíže a váhání nad volbou nejvhodnějšího výrazu lze vystopovat ještě v jednom typu vysvětlivek, nabízejícím alternativní překladovou variantu.

Př́íklady tohoto typu:

(15) Kvielila a potuchla jest země a zemdlela. Splynul svět a zemdlela jest výsost lida země (točíš zemského) (Iz 24,4)

(16) ... hlas tvój a z země výmluva tvá (točíš mluvenie tvé) bublati bude (Iz 29,4)

(17) I činil jest zlý skutek před hospodinem (točíš před očima božíma) (Jr 52,2)

(18) A dám (točíš učiním) horu Seir opustělú a pustú (Ez 35,7)

(19) ... čtverohranatý rovnými stranami (točíš úhly) $($ Ez 43,16)

Upozornit bychom chtěli zejména na verš Jr 52,2, který zároveň dobře reprezentuje pro první překlad obvyklý postup, kdy je překládán v prvé řadě smysl textu a ne jeho doslovné znění. Hodnota tohoto přistupu ještě víc vynikne při porovnání prvního překladu s překladem třetím, který je naopak známý preferováním doslovnosti překladu, a to až na práh srozumitelnosti textu - Bible Padeřovská toto místo překládá: před očima páně. Doplnění vysvětlivky na tomto místě zároveň naznačuje, že si této výraznější volnosti překladu byli autoři dobře vědomi a částečně, jako i v tomto př́padě, ji mírnili doplňováním doslovnějšího znění. Obrácený postup můžeme naopak sledovat u slovesa dare, které je $\mathrm{v}$ textu ponecháno v jeho základní významu, alespoň v poznámce je však doplněn pro české prostředí náležitějším překladem učiniti.

\subsubsection{Vysvětlivky významově-interpretačni}

Druhou skupinu tvoří vysvětlivky tzv. významově-interpretační. Ty se vztahují př́mo k obsahu sdělení a napomáhají čtenáři jeho pochopení, příp. 
nabízejí možnou interpretaci některých míst. Právě tato skupina tak měla největší vliv na čtenáře a zvláště v místech nabízejících více možných interpretací přispívala $\mathrm{k}$ utvrzení a přijetí předložené interpretace.

Je nepochybné, že k tomuto typu vysvětlivek přistupovali autoři s velkou opatrností - jednalo se o teologicky zásadní text -, a často proto hledali inspiraci v dílech uznávaných autorů. Původ některých výkladů tak můžeme najít zejména u Petra z Troyes a Mikuláše Lyry. Není proto divu, že právě tito autoři měli velký vliv na českou duchovní elitu druhé půli 14. stol. a jejich výsostné postavení můžeme, jako zvláště v případě Mikuláše Lyry, sledovat i na počátku století 15., kdy se stává jedním z duchovních zdrojů českého husitství.

Po formální stránce jsou oproti předchozím typům tyto vysvětlivky vždy od textu oddělené pomocí uvozovacích výrazů totiž, to jest, točišto ap., čímž je také jasně signalizována jejich oddělenost od textu. Největší skupinu zde tvoří výklady četných obrazných pojmenování objevující se v biblickém textu či upřesnění některých významově příliš obecných slovních spojení.

Př́íklady tohoto typu:

(20) ... a malichná sě učinila ruka (točíš moc) má (Iz 50,2)

(21) ... aby činily mazancě a pokrmy královně nebeské (točíš měsieci) $(\mathrm{Jr} 7,18)$

(22) ... a zadky obracijíc (točíš poběhujíc z boje) (Jr 46,5)

(23) ... jediné ač potrhnú maličcí z stáda (točíš chaternější z lidí) (Jr 50,45)

(24) ... zlámali prsi děvojného věku jejie (točíš děvojstvo jejie otjali) (Ez 23,8)

Z tohoto výčtu bychom chtěli upozornit zejména na verš Iz 50,2 kde je lat. manus překládané v základním významu jako ruka př́íslušný význam je však upřesněn vysvětlivkou ,točíš moc”. Toto doplnění (nutno říci, že se jedná o prríměr v této době poměrně obvyklý) se v textu objevuje opakovaně a snad by se dalo označit za jisté překladatelovo specifikum. Podobně soustavněji je doplňováno sloveso umřieti za jednotlivé v textu užité opisy.

Př́klady tohoto typu:

(25) A zakryji, když uhasneš (točíš umřeš) (Ez 32,7)

(26) ... a v svú sílu úfali sú, jížto sú usnuli (točíš umřěli) (Ez 32,30) 
(27) A zatiem král Astyages přiložen jest k svým otcóm (točíš umřěl) (Dn 13,65)

Možným způsobem, jak napomoci čtenáři s náležitou interpretací některých syntakticky obtížnějších struktur, bylo i doplňování explicitně nevyjádřených částí věty, či usouvztažňování v textu užitých pronomin s výrazy, které zastupovaly.

Př́klady tohoto typu:

(28) I stalo sě jest slovo božie k Jeremiášovi, jakž jest zlámal Ananiáš prorok řetěz s hrdla jeho (točíš Jeremiášova proroka) $(J r 28,12)$

(29) Ale ona (točíš ta diela) ... (Bar 6,62)

(30) Krajené tvoji (točíš Sidonští) ... (Ez 27,4)

(31) ... jenž toho všeho nebude činiti (točíš dobrých skutkóv nebude činiti) $(\mathrm{Ez} 18,11)$

Nás však zejména zajímalo, zda se ve sledovaném úseku nacházejí i vysvětlivky, které by bylo možné označit jako výrazněji interpretační. Pro celý první překlad platí, (a tak o tom hovoří i Vladimír Kyas 1971: 57), že se v doplňujících komentářích autoři vyvarovali náboženských polemik - a tento typ vysvětlivek se opravdu v textech nevyskytuje - přesto by bylo možné některé komentáře považovat za jistý pokus o ovlivnění čtenářovy interpretace textu v duchu křest’anské věrouky.

Př́ḱlady tohoto typu:

(32) Toho dne bude plod boží u velebnosti a v chvále a ovoce zemské vysoké a povýšenie těm, jížto živi ostanú z izrahelského lidu (točíž spaseni budú) $($ Iz 4,2)

(33) I stane sě, že toho dne navštieví hospodin na rytieřstvo nebeské (točíš na diábly) na výsosti (Iz 24,21)

(34) A sberú sě sebráním jednoho snopa $v$ močidlo (točíš $\mathbf{v}$ peklo) (Iz 24,22)

(35) ... aby byl mně sluha k vzkřiešení pokolení Jakubových a kvasnic (točíš ostatkóv) izrahelských (Iz 49,6)

(36) ... a umyl sem tě vodú a očistil sem krev tvú (točíš hřiech tvój) s tebe a pomazal sem tě olejem (Ez 16,9) 
(37) A protož ty také nes hanbu tvú, jěžto si přemohlo sestry tvé hřiechy tvými škaředějie čině než ony, neb sú sě zpravily tebú (točíš tiem, že sú méně hř̌̌šily) (Ez 16,52)

(38) A když sě otvrátí nepravý ot své nepravosti, jižto jest činil, a bude činiti súd a spravedlnost, ten také duši svú očistí (točíš spasí) (Ez 18,27)

(39) A vzkřiesím jim plod spravedlný jmenovaný a nebudú viece navštieveni hladem v zemi ani ponesú (točíš trpěti budú) viece potupu lidskú (Ez 34,29)

(40) I stalo sě jest nade mnú ruka (točíš zjěvenie) božie a vyvedši mě v duchu božiem i pustila mě prostřed pole, ješto bylo plné kostí (Ez 37,1)

(41) Zatratil sem lidi a rozpuzeni jsú anjelové (točíš kniežata) jeho, pusté si učinil cěsty jeho, když nenie, kto by chodil po nich (So 3,6)

V duchu křest’anské nauky je tak vykládáno např. očištěni ve verši Ez 18,27 jako „spasení”, v symbolickém smyslu pak krev je ve verši Ez 16,9 vykládána coby hřich a poměrně výrazným pokusem o interpretaci textu je i označení rytieřstva nebeského, na které padl boží hněv ve verši Iz 24,21, již jako „dábly (takto jasné spojení si nedovolila z pozdějších biblí ani bible Kralická, která zde ponechává pouze překlad: „vojsko vysoké na výsosti”, podobně pak novodobé ekumenické vydání Bible ponechává na tomto místě překlad „nebeský zástup na výšině” (Bible 1996). Je tedy patrné, že ovlivnění čtenářské interpretace textu je v prŕípadě tohoto typu vysvětlivek skutečně poměrně značné.

\section{Vysvětlivky v následujících biblických překladech}

Pohled na staročeské vysvětlivky a jejich vliv by nebyl úplný, kdybychom se na závěr v krátkosti nepodívali, jak k nim přistupovaly následující biblické překlady. Tento pohled nám může napomoci pochopit rozdíl v chápání jednotlivých skupin a typů.

Velmi jasná situace je v případě dvou nejmladších staročeských překladů, v třetí a čtvrté redakci. Třetí biblický překlad je považován za překlad nejdůsledněji se držící vulgátní předlohy, často až na úkor srozumitelnosti textu, a není proto překvapující, že veškeré doplňující nevulgátní komentáře prostě vypouští. Velmi podobně pak k této otázce přistupuje i redakce čtvrtá. Ani ta vysvětlivky ve svém znění téměř neponechala (např. v knize Ezechiel zůstá- 
vají jen jednoslovná doplnění u velmi neprůhledných pojmenování měr a vah hint, siclus a efi).

Co se týče druhé redakce, př́stup k vysvětlivkám byl v této skupině poměrně individuální a míra jejich užití se $\mathrm{v}$ jednotlivých památkách výrazně lišila. Bližší rozbor jednotlivých výskytů navíc naznačil, že množství ponechávaných vysvětlivek nesouvisel patrně ani s př́íslušností jednotlivých biblí k mladší nebo starší verzi druhého překladu a závisel tedy především na rozhodnutí daného zhotovitele konkrétní památky.

Nejméně mizící skupinou je typ vysvětlivek propriálních, a to zejména v př́ípadech, kdy vysvětlivka nebyla nijak signalizována. Takováto jednoslovná upřesnění patrně ani nebyla vnímána jako text doplněný nad rámec Vulgáty. Oproti tomu zbylé typy byly v jednotlivých památkách zachovávány v rozlišné míře. Hodna zaznamenání je skutečnost, že vysvětlivky nebyly často přejímány zcela doslovně, ale byly různě obměňovány. Nejproměnlivějši částí přitom byla sama odkazující formule, která byla $v$ jednotlivých druhoredakčních památkách různě upravována a měněna, nikdy však vynechána.

Doba, po kterou se vysvětlivky v biblických textech objevovaly, tedy nebyla prŕiliš dlouhá. V prvních údobích života biblického př̀kladu byly však nepostradatelnou pomůckou pro pochopení textu. Způsob, jak bylo s vysvětlivkami a jejich signalizací v následujících staročeských překladech nakládáno zároveň naznačuje, že překladatelé (a patrně i recipienti textu) si byly jejich odvislosti od biblického textu vědomi a dokázali tedy rozlišovat mezi jednotlivými textovými rovinami. Z těchto důvodů mohou být dnes bohatým zdrojem poznání jak o tehdejší překladatelské praxi, tak také o způsobech interpretace biblického textu, na jejichž formování se zároveň svým působením výrazně spolupodílely.

\section{Bibliografie}

Bartoš F. M., 1941, Počátky české bible, Praha: Kalich.

Bible, 1996, Český ekumenický překlad, Praha: Česká biblická společnost.

Bible Kralická, 1579-1593, Kralice, Knihopis 1107.

Bible Olomoucká, 1417, Olomouc, SVK III1/I, II.

Bible Padeřovská, 1432-1435, Vídeň, NK 1175.

Kyas V., 1971, První český překlad bible, Praha: Academia. 
PүтLíková M., 2010, Vysvětlivky ve staročeském překladu Makabejských knih, w: Varia 19. Zbornik plných príspevkov z 19. kolokvia mladých jazykovedcov, Trnava: Trnavská univerzita v Trnave, s. 286-291.

\section{The Explanatory Notes in the old Czech translation of the biblical prophetic books}

\section{( su m mary)}

The paper is devoted to the translation of the explanatory notes in the text of the oldest Czech translation of the Bible. These are mostly short, one or several words parentheses, which were supplied by translators of the biblical text in places which they considered too difficult for Czech recipients (there are descriptions of some unknown biblical realia, explanations of some unusual poetic images, etc.). In the paper we described those notes and explored their possible pragmatic use. Particular focus was devoted to their potential to comprehend the text in the spirit of the Christian interpretation. In the final part comparison is offered with the other old Czech translations. 